\title{
Preparation and Application of Titanate Nanotubes on Dye Degradation from Aqueous Media by UV Irradiation
}

\author{
Rui Liu, ${ }^{1}$ Wein-Duo Yang, ${ }^{2}$ Hui-Ju Chueng, ${ }^{2}$ and Bin-Qiao Ren ${ }^{3}$ \\ ${ }^{1}$ Institute of Petroleum and Commodity, Harbin University of Commerce, 138 Tongda Street, Harbin 150076, China \\ ${ }^{2}$ Department of Chemical and Materials Engineering, National Kaohsiung University of Applied Sciences, 415 Chien-Kung Road, \\ Kaohsiung 807, Taiwan \\ ${ }^{3}$ Institute of Advanced Technology of Heilongjiang Academy of Sciences, 135 Nanma Road, Harbin 150020, China
}

Correspondence should be addressed to Rui Liu; 57776806@qq.com and Wein-Duo Yang; ywd@cc.kuas.edu.tw

Received 30 June 2014; Accepted 15 July 2014

Academic Editor: Tifeng Jiao

Copyright (C) 2015 Rui Liu et al. This is an open access article distributed under the Creative Commons Attribution License, which permits unrestricted use, distribution, and reproduction in any medium, provided the original work is properly cited.

Titanate nanotubes were synthesized by a hydrothermal method using commercial $\mathrm{TiO}_{2}$ powder and then used as a photocatalyst. The titanate nanotubes were synthesized by varying the hydrothermal temperature from $110^{\circ} \mathrm{C}$ to $180^{\circ} \mathrm{C}$. The morphological changes and phase transformation of the $\mathrm{TiO}_{2}$ nanotubes were analyzed by X-ray diffraction (XRD), scanning electron microscopy (SEM), and transmission electron microscopy (TEM). The particles' scattering behavior was investigated by Raman studies, and the surface area of the nanotubes was determined by a Brunauer, Emmett, and Teller (BET) analysis. Comparative studies show that the surface area of nanotubes increases with increasing temperature up to $130^{\circ} \mathrm{C}$. The catalytic behavior of the synthesized nanotubes was also studied. The as-prepared titanate nanotubes were applied to methylene blue (MB, an organic dye) degradation in aqueous media by UV irradiation. Approximately $99 \%$ of the dye was removed from the aqueous media using $2 \mathrm{~g} / \mathrm{L}$ titanate nanotube when the initial dye concentration was $9 \mathrm{mg} / \mathrm{L}$. The total irradiation time was $2 \mathrm{~h}$.

\section{Introduction}

Nanoparticles and their applications are of great interest in modern science due to their unique properties, which differ from those of the corresponding bulk materials, and their diverse applications [1-4]. Gold, silver, ruthenium, platinum, and bimetallics or nanoalloys of those elements have been synthesized in various ways and used in biochemistry in particular for biomedical applications [5-10]. Among these materials, Titania $\left(\mathrm{TiO}_{2}\right)$ is believed to be the most promising due to its nontoxicity, long-term stability, and low cost. Its applications are strongly dependent on the crystallographic structure, morphology, and size of the particles. Due to its desirable band gap $(3.2 \mathrm{eV}), \mathrm{TiO}_{2}$ nanoparticles are also used in solar cells. It is also worth mentioning that Titania nanotubes and nanowires are used as photocatalysts due to their strong oxidizing power, biological and chemical inertness, and long-term stability against light-based and chemical corrosion $[11,12]$. Presently, groups of researchers are attempting to use this nanoparticle to remove toxic contaminants from aqueous media and air for the remediation of environmental contamination [13-15].

Various synthetic routes have been explored for the synthesis of size-controlled $\mathrm{TiO}_{2}$ nanoparticles. The simple hydrolysis of titanium salts results in $\mathrm{TiO}_{2}$ nanoparticles [1619]. However, this technique produces a mixture of anatase and rutile polymorphs, which inhibits the formation of well-shaped anatase nanocrystals $[20,21]$, which have the highest photocatalytic activity towards the degradation of most organic contaminants in aqueous media [20]. Several groups have reported the preparation of titanate nanotubes (TNTs) using different hydrothermal reaction temperatures and durations $[22,23]$. This method does not require a template, and the obtained nanotubes have a small diameter $(\sim 10 \mathrm{~nm})$ with high crystallinity. Many groups have tried to analyze the characteristics of TNTs, which can then be used to evaluate the synthetic mechanism as well as sheet-folding mechanism $[24,25]$. TNTs derived from the hydrothermal 
method possess ion-exchange properties and are characterized by a high surface area and pore volume. They may also offer a special environment for the adsorption of large cations, such as basic dyes. Moreover, the hydrothermal method is also a simple, cost-effective, and ecofriendly technology and can prepare TNTs in high yields. Therefore, examining the potential applications of TNTs synthesized from this method, which is ecofriendly and cost-effective, is important.

Water pollution due to organic dyes is of great concern for human health as well as the environment because colored water is aesthetically unpleasant. The production of different by-products due to the degradation of some organic dyes poses a severe health risk due to their carcinogenicity. The literature contains physical, chemical, and biological methods that have been applied to remove the color from dyecontaminated wastewater [26-30], and physical adsorption has been identified as a potentially efficient and economical way to remove dyes from waste streams and control the biochemical oxygen demand [31]. Although activated carbon is believed to be an efficient adsorbent for organic hazardous removal from aqueous media, it is expensive. Hence, a number of groups have tried to remove toxic organic dyes from aqueous media using titanate nanotubes by activating its photocatalytic activity using UV irradiation. $\mathrm{TiO}_{2} / \mathrm{UV}$ photocatalysis is among the most promising advanced oxidation technologies due to the effectiveness of $\mathrm{TiO}_{2}$ in generating hydroxyl radicals along with its environmentally benign properties and relatively low cost [32-34].

In this paper, we have focused on the synthesis of titanate nanotubes using a hydrothermal method with different reaction temperatures and times. The performances of the titanate nanotubes synthesized under different reaction temperatures were analyzed analytically by XRD, Raman, TEM, BET, and FTIR. Finally, the removal of an organic dye, methylene blue (MB), was from an aqueous environment attempted using the synthesized titanate nanotubes and UV irradiation.

\section{Materials and Methods}

2.1. Reagents. All the chemicals used were of analytical grade and were used as received. $\mathrm{HNO}_{3}, \mathrm{NaOH}, \mathrm{TiO}_{2}(\mathrm{P} 25)$ powder, and methylene blue (MB) were purchased from Acros Organics (New Jersey, USA). A 100 ppm stock MB solution was prepared in double-distilled water and diluted as required.

2.2. Instrumentation. All the glass apparatus used were soaked in concentrated $\mathrm{HNO}_{3}$ for $12 \mathrm{~h}$ and then washed with large volumes of double-distilled water followed by tap water. Next, the apparatus were dried in a hot-air oven for $2 \mathrm{~h}$ at $90^{\circ} \mathrm{C}$. A high-precision electronic balance was used for weighing, and a high-precision digital electronic $\mathrm{pH}$ meter was used to measure the $\mathrm{pH}$ of the medium. FTIR spectrometry was conducted using a Bio-Rad Digilab FIS165 spectrophotometer. A Lambda Dimension-P2 Raman spectrometer was used to measure the Raman shift. Powder XRD patterns were recorded using a PANalytical X'Pert PRO $\mathrm{X}$-ray diffractometer with $\mathrm{CuK} \alpha(\lambda=1.5406 \AA)$ radiation. A

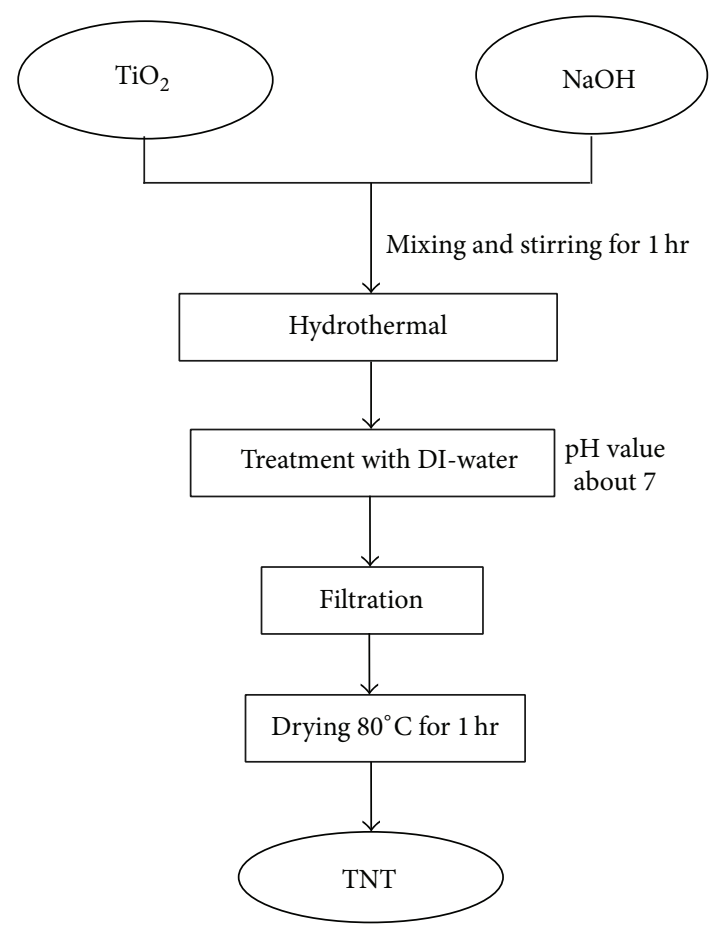

FIGURE 1: Preparation of titanate nanotubes by the hydrothermal method.

Micromeritics ASAP 2101 instrument was used for BET analysis. TEM measurements were performed using a Philips M200 transmission electron microscope operating at $200 \mathrm{kV}$. All absorbance measurements were carried out using a UVVis spectrophotometer (HITACHI, U-2800) equipped with a $1 \mathrm{~cm}$ quartz cell. Gilson micropipette and microtips were used to add samples.

2.3. Preparation of Titanate Nanotubes. Hydrothermally titanate nanotubes were synthesized and the total synthesis process is shown in Figure 1. Set of experiments were conducted by the mixing of commercially available $(0.8 \mathrm{~g})(\mathrm{P} 25)$ $\mathrm{TiO}_{2}$ powder in $50 \mathrm{~mL}$ aqueous $\mathrm{NaOH}(10 \mathrm{M})$ solution. The mixtures were allowed to continuous stirring for $1 \mathrm{~h}$ with a magnetic stirrer. After the aging time finished, the reactions mixtures were hydrothermally treated at different temperatures in a stainless Teflon-lined autoclave. The autoclave was put into an oven and was heated to $110-180^{\circ} \mathrm{C}$ for a prescribed period of $24 \mathrm{~h}$ and cooled to room temperature naturally in air. Next, the final reaction products were washed thoroughly with large volumes of double-distilled water to achieve the neutral $\mathrm{pH}$ of the medium and that is $\sim 7$. Finally, obtained white cotton-batting-like solid was filtrated and dried at $80^{\circ} \mathrm{C}$ for $1 \mathrm{~h}$ and then characterized and used for photodegradation of organic dye, methylene blue from aqueous media.

2.4. Photocatalytic Degradation of Aqueous Methylene Blue $(M B)$. To investigate the photocatalytic activity of the synthesized titanate nanotubes, the degradation of a toxic organic dye, methylene blue $\left(\mathrm{C}_{16} \mathrm{H}_{18} \mathrm{ClN}_{3} \mathrm{~S}\right)$ (Figure 2), in aqueous 
<smiles>CN(C)c1ccc2c(c1)[SH]=c1cc(N(C)Cl)ccc1=N2</smiles>

Figure 2: Structure of MB.

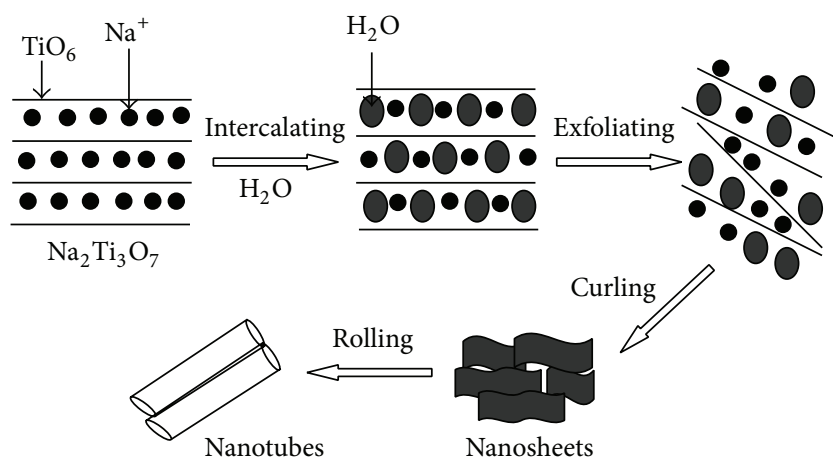

FIGURE 3: Exfoliating-rolling model of nanotube formation from the layered $\mathrm{Na}_{2} \mathrm{Ti}_{3} \mathrm{O}_{7}$ particles by a soft chemical process.

media was attempted using UV irradiation. First, $0.2 \mathrm{~g}$ of as-prepared titanate nanotubes was dispersed in $100 \mathrm{~mL}$ of synthetic MB solution when the initial dye concentration was $9 \mathrm{mg} / \mathrm{L}$ (titanate nanotubes dose, $2 \mathrm{~g} / \mathrm{L}$ ). The mixture of dye and catalyst was then placed in a photocatalytic reactor and subjected to UV irradiation. A 6-W, $254 \mathrm{~nm}$ UV lamp was used as the light source. The aqueous system of the suspended catalyst was oxygenated to ensure the presence of sufficient oxygen in the system. The experiment was conducted at room temperature $\left(\sim 25 \pm 2^{\circ} \mathrm{C}\right)$. The total UV irradiation time was $2 \mathrm{~h}$. Next, the titanate nanotube suspension was centrifuged at $3200 \mathrm{rpm}$ for $10 \mathrm{~min}$ to separate the solid and liquid phases. Collecting the supernatant liquid, after centrifugation, the remaining dye concentration in the solution was measured by UV-Vis spectrophotometry at $669 \mathrm{~nm}$.

\section{Results and Discussion}

3.1. Formation Mechanism of Titanate Nanotubes. $\mathrm{Na}^{+}$resides between the edge-shared $\mathrm{TiO}_{6}$ and $\mathrm{Na}_{2} \mathrm{Ti}_{3} \mathrm{O}_{7}$ octahedral layers, as is well known. The strong static interaction force between the $\mathrm{Na}^{+}$and $\mathrm{TiO}_{6}$ units holds the layers together tightly and makes it impossible to roll these layers into nanotubes. Under the hydrothermal conditions, $\mathrm{Na}^{+}$is gradually released with intercalated $\mathrm{H}_{2} \mathrm{O}$ molecules into the interlayer space of the $\mathrm{TiO}_{6}$ sheets. Because $\mathrm{H}_{2} \mathrm{O}$ molecules are larger than $\mathrm{Na}^{+}$ions, the interlayer distance increases during the release of $\mathrm{Na}^{+}$, weakening the static interaction force between neighboring $\mathrm{TiO}_{6}$ and octahedral sheets. As a result, the $\mathrm{Na}_{2} \mathrm{Ti}_{3} \mathrm{O}_{7}$ layer was gradually exfoliated to form numerous sheet-shaped products $[32,33]$. The nanotube formation mechanism is shown in Figure 3 [35].

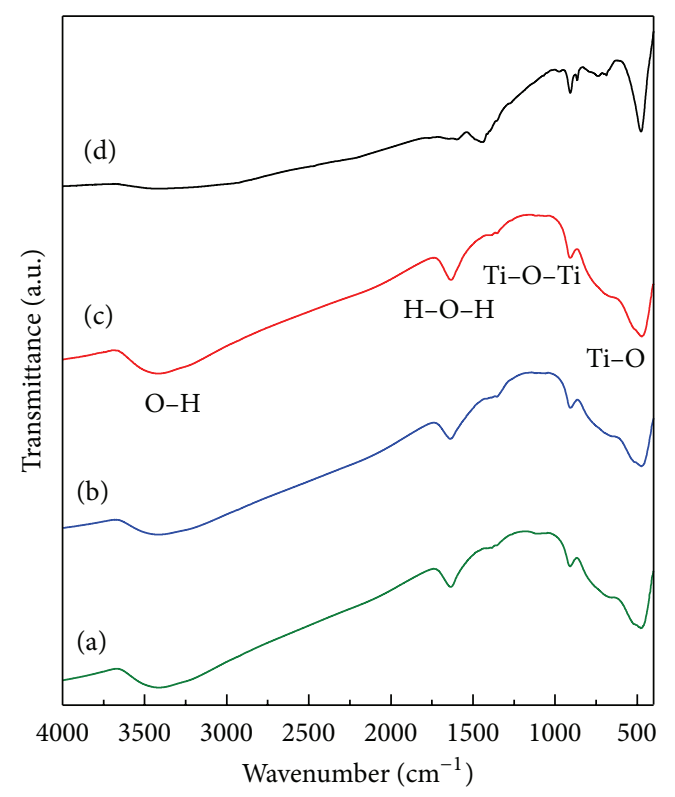

FIGURE 4: FTIR spectra of the samples prepared at different reaction temperatures: (a) $110^{\circ} \mathrm{C}$, (b) $130^{\circ} \mathrm{C}$, (c) $150^{\circ} \mathrm{C}$, and (d) $180^{\circ} \mathrm{C}$.

3.2. Characterization of Titanate Nanotubes. The synthesized titanate nanotubes were characterized by different methods. Figure 4 shows the FTIR spectra of the as-prepared nanotubes (using $\mathrm{KBr}$ pellets) synthesized at different hydrothermal temperatures and compares these values to those from a previous work [36]. The broad peaks at $3200 \sim 3400 \mathrm{~cm}^{-1}$ are ascribed to the stretching vibration of the hydroxyl groups $(\mathrm{O}-\mathrm{H})$ from the residual water in the precursors. The peak of $1630 \mathrm{~cm}^{-1}$ is attributed to the bending vibration of the hydroxyl groups $(\mathrm{H}-\mathrm{O}-\mathrm{H})$ present in the titanate nanotubes. The other broad bands at $700 \sim 1200 \mathrm{~cm}^{-1}$ and $300 \sim 900 \mathrm{~cm}^{-1}$ are assigned to the Ti-O and Ti-O-Ti skeletal frequency regions, respectively. As the hydrothermal temperature increased to $180^{\circ} \mathrm{C}$, the peaks of the stretching $(\mathrm{O}-$ $\mathrm{H})$ and bending $(\mathrm{H}-\mathrm{O}-\mathrm{H})$ vibrations of the hydroxyl groups disappeared completely. This disappearance is due to the very low content of organic compounds and water at high reaction temperatures.

The X-ray diffraction patterns (XRD) of titanate nanotubes synthesized at different hydrothermal temperatures are shown in Figure 5. The intense peak at approximately $9.1^{\circ}$ is thought to be due to the layered structure of the $\mathrm{NaHTi}_{3} \mathrm{O}_{7}$ nanotube wall, while the smaller broad peaks at approximately $24^{\circ}, 28^{\circ}$, and $48^{\circ}$ suggest the presence of sodium $(\mathrm{Na})$ in the synthesized nanotubes, for example, $\mathrm{Ti}_{6} \mathrm{O}_{13}, \mathrm{Ti}_{6} \mathrm{O}_{12}$, and $\mathrm{Ti}_{9} \mathrm{O}_{18}$. However, as the hydrothermal temperature increases to $180^{\circ} \mathrm{C}$, curve (d) of Figure 5 suggests the presence of $\mathrm{Na}_{2} \mathrm{Ti}_{6} \mathrm{O}_{13}$, the hydrothermally synthesized product [36-39]. This finding indicates that the titanate nanotube structure is changing from tube to rod. The nanorods are formed by the parallel arrangement of the nanotubes, which is a result of the adsorption of the nanotube surface of the water molecules and the evaporation of the inner layer 


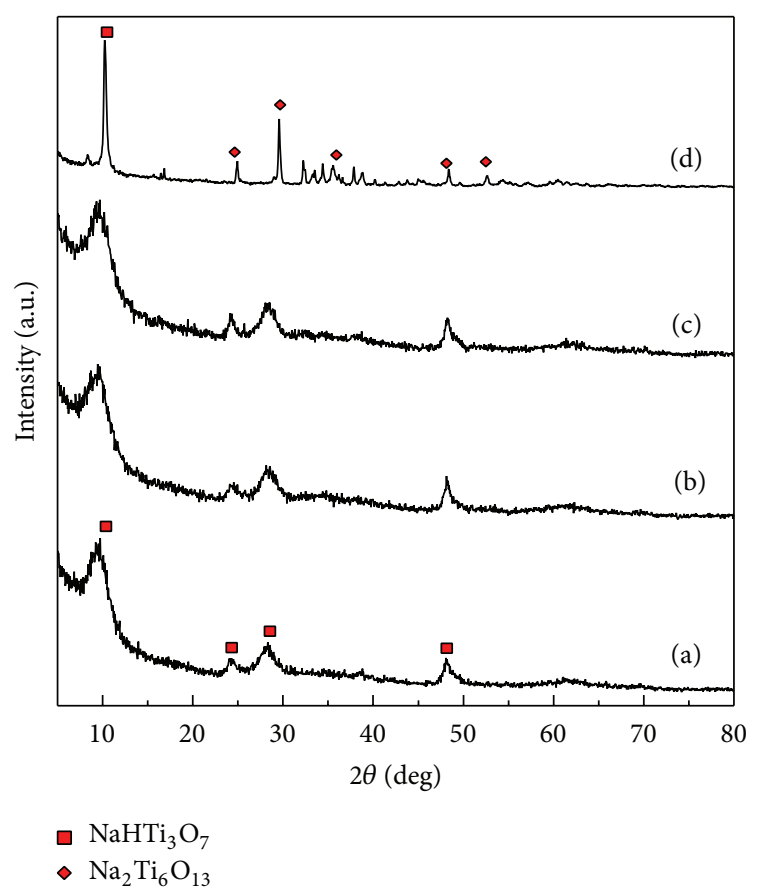

FIGURE 5: XRD patterns of the samples prepared at different reaction temperatures: (a) $110^{\circ} \mathrm{C}$, (b) $130^{\circ} \mathrm{C}$, (c) $150^{\circ} \mathrm{C}$, and (d) $180^{\circ} \mathrm{C}$.

of moisture to release the high stress inside the nanotube structure.

Figure 6 shows the TEM images of titanate nanotubes hydrothermally synthesized at different temperatures. When the hydrothermal treatment temperature was $110^{\circ} \mathrm{C}$, the tubular structure was absent, and sheet-like structures were observed. Titanate nanotube clusters can be clearly seen when the hydrothermal treatment temperature was increased to $130^{\circ} \mathrm{C}$. As the hydrothermal temperature increased to $180^{\circ} \mathrm{C}$, the titanate nanotubes adopted a rod-like structure. It is inferred that the tubular structure is clearer and tube pore diameter larger at high hydrothermal temperatures. Overall, no damage of the titanate nanotubes was observed during the hydrothermal process with increasing temperature. The nanotubes were $200 \sim 300 \mathrm{~nm}$ in length and approximately $10 \mathrm{~nm}$ in diameter. Some of the long tubes synthesized at high temperature broke into shorter tubes. The tubular structure was retained, but the tubes were deposited onto one another $[37,40]$.

The surface morphology of the synthesized nanotubes was monitored by SEM (JEOL, TFSEM-6330), and the micrographs are shown in Figure 7. Figure 7 implies that the nanotube formation depends on temperature. The formation of nanotubes is due to the warping or splitting of the surface of $\mathrm{Na}_{2} \mathrm{Ti}_{3} \mathrm{O}_{7}$ octahedral layers. A number of cumulative steps followed the formation of nanotubes. Figure 8 depicts the $\mathrm{H}_{2} \mathrm{Ti}_{3} \mathrm{O}_{7}$ nanotube and nanowire formation processes. Initially, lamellar structures were grown on the brim of $\mathrm{TiO}_{2}$ particles. These lamellar structures grow along the [001] direction with the (010) plane as the top/bottom surface (a). Second, the lamellar structures split into nanosheets between
TABLE 1: BET analysis of as-prepared titanate nanotubes at different temperature and after $24 \mathrm{~h}$.

\begin{tabular}{lccc}
\hline $\begin{array}{l}\text { Sample at different } \\
\text { temperature }\end{array}$ & $S_{\mathrm{BET}}\left(\mathrm{m}^{2} / \mathrm{g}\right)$ & $\begin{array}{c}\text { Pore volume } \\
\left(\mathrm{cm}^{3} / \mathrm{g}\right)\end{array}$ & Size $(\mathrm{nm})$ \\
\hline $\mathrm{P} 25$ & 60.0 & 0.06 & 3.8 \\
$110^{\circ} \mathrm{C}$ & 126.7 & 0.20 & 3.2 \\
$130^{\circ} \mathrm{C}$ & 186.8 & 0.23 & 3.2 \\
$150^{\circ} \mathrm{C}$ & 183.6 & 0.39 & 4.8 \\
$180^{\circ} \mathrm{C}$ & 9.9 & 0.05 & 11.6 \\
\hline
\end{tabular}

TABLE 2: BET analysis of the prepared titanate nanotubes at different time at constant temperature of $130^{\circ} \mathrm{C}$.

\begin{tabular}{lccc}
\hline $\begin{array}{l}\text { Sample at different } \\
\text { time }\end{array}$ & $S_{\text {BET }}\left(\mathrm{m}^{2} / \mathrm{g}\right)$ & $\begin{array}{c}\text { Pore volume } \\
\left(\mathrm{cm}^{3} / \mathrm{g}\right)\end{array}$ & Size $(\mathrm{nm})$ \\
\hline P25 & 60.0 & 0.06 & 3.8 \\
$12 \mathrm{~h}$ & 161.0 & 0.30 & 3.7 \\
$24 \mathrm{~h}$ & 186.8 & 0.31 & 3.3 \\
$48 \mathrm{~h}$ & 170.3 & 0.28 & 3.3 \\
\hline
\end{tabular}

the (100) planes. The height of these nanosheet structures (in the $b$ direction) is the thickness of the original lamellar structure (b). In the third step, the nanosheets wrapped into nanotubes with diameters dependent on the height of the nanosheets (c). Additionally, thick layers or wires may be formed after prolonged reaction at elevated temperature (d). Afterwards, splitting may occur between the (100) and (010) planes of these thick layers or wires (e). Finally, further splitting leads to the formation of thin nanowires (d) [41].

The nanotubes synthesized at various temperatures for various durations were subjected to BET analysis to determine the surface area of the synthesized titanate particles after degassing with nitrogen. The obtained result is given in Table 1. The specific surface area of the nanotubes increased with temperature, which in turn proves that the nanotubes are relatively small. This result can be interpreted as the titanate nanotubes steadily turning into tubular nanocomposites. At temperatures above $130^{\circ} \mathrm{C}$, the surface area slowly decreases, which indicates that the nanotubes became larger (Table 1). The maximum surface area of the nanotubes, $186.8 \mathrm{~m}^{2} / \mathrm{g}$, was produced at $130^{\circ} \mathrm{C}$ after $24 \mathrm{~h}$ of synthesis. A time-resolved study of the surface area of the synthesized nanotubes was also conducted by varying the synthesis duration from 0 to $48 \mathrm{~h}$, keeping the temperature constant at $130^{\circ} \mathrm{C}$. It is observed that the surface area of the nanotubes increases with reaction time at this constant temperature. The time dependence of the nanotube surface area can be attributed to a continuous conversion of nanosheets into nanotubes during the reaction time. However, the obtained result suggests that the maximum surface area, $186.8 \mathrm{~m}^{2} / \mathrm{g}$, is found after $24 \mathrm{~h}$ of synthesis (Table 2). In contrast, this value was $60 \mathrm{~m}^{2} / \mathrm{g}$ for P25 under room-temperature conditions. 


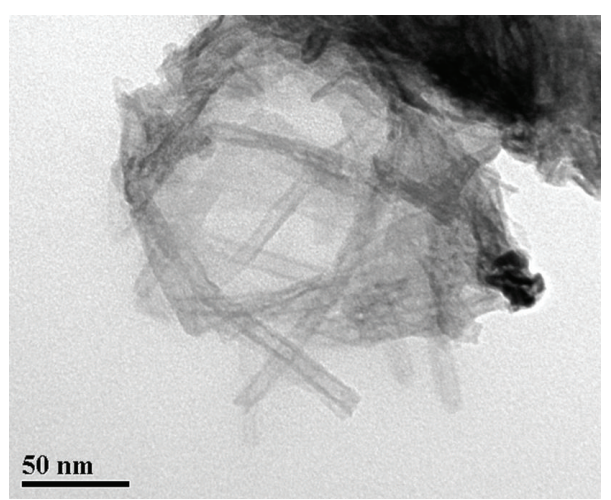

(a)

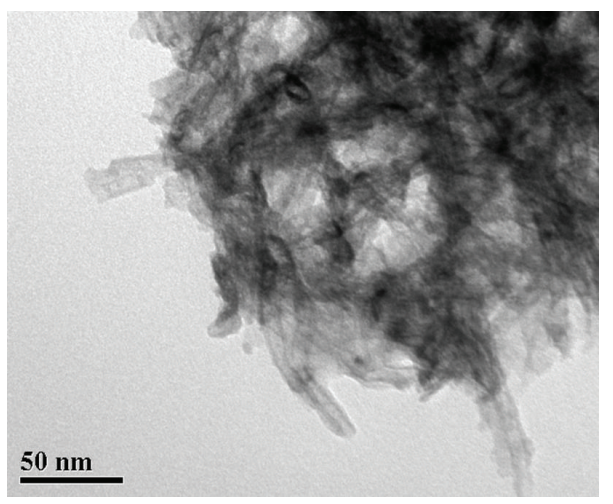

(c)

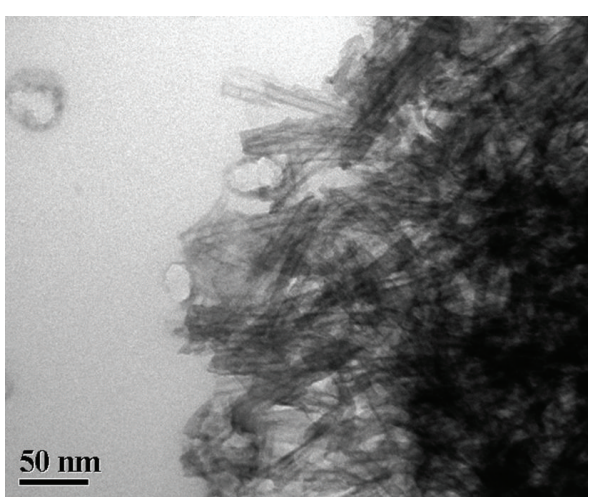

(b)

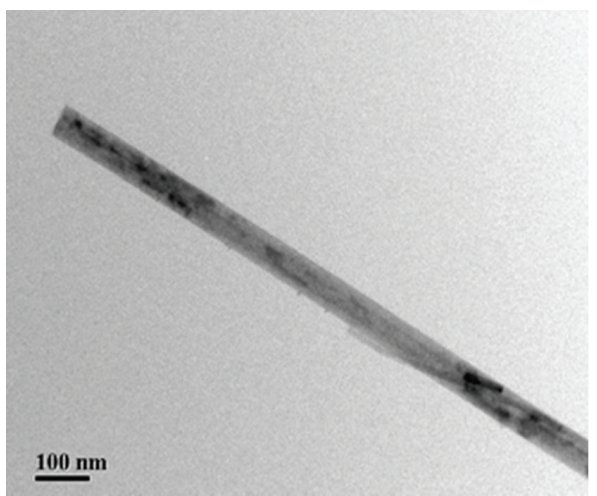

(d)

FIgURE 6: TEM images of the samples prepared at different reaction temperatures: (a) $110^{\circ} \mathrm{C}$, (b) $130^{\circ} \mathrm{C}$, (c) $150^{\circ} \mathrm{C}$, and (d) $180^{\circ} \mathrm{C}$.

The Raman spectrum of the as-prepared nanotubes is shown in curve (a) in Figure 9. For hydrothermal temperatures below $150^{\circ} \mathrm{C}$, the modes at $662 \mathrm{~cm}^{-1}$ and $700 \mathrm{~cm}^{-1}$ are ascribed to the vibrations of $\mathrm{Ti}-\mathrm{O}-\mathrm{Na}$ and $\mathrm{Ti}-\mathrm{O}-\mathrm{H}$, respectively, given that the $662 \mathrm{~cm}^{-1}$ mode disappears from the as-prepared sample after washing with deionized (DI) water, which proves the exchange of $\mathrm{Na}^{+}$by $\mathrm{H}^{+}$. The $910 \mathrm{~cm}^{-1}$ mode can be ascribed to the vibrations of $\mathrm{Ti}-\mathrm{O}$, which indicates that the structure is $\mathrm{NaHTi}_{3} \mathrm{O}_{7}$. At $180^{\circ} \mathrm{C}$, the characteristic peaks of $\mathrm{NaHTi}_{3} \mathrm{O}_{7}$ disappeared, while the Raman modes at $197 \mathrm{~cm}^{-1}, 224 \mathrm{~cm}^{-1}, 278 \mathrm{~cm}^{-1}, 306 \mathrm{~cm}^{-1}$, $414 \mathrm{~cm}^{-1}, 475 \mathrm{~cm}^{-1}, 680 \mathrm{~cm}^{-1}$, and $874 \mathrm{~cm}^{-1}$ were strongly consistent with the previously reported results, which once again supports the presence of titanate nanotubes in the products synthesized by the hydrothermal process $[36,39]$.

\subsection{Photocatalytic Degradation of $M B$}

3.3.1. Calibration Curve. UV-Visible spectra were recorded with various dye concentrations and are shown in Figure 10. The study was first conducted without the addition of the titanate nanotube photocatalyst or UV irradiation. A linear calibration curve of $\mathrm{MB}\left(\lambda_{\max }=669 \mathrm{~nm}\right)$ was drawn in the concentration range of $0-18 \mathrm{mg} / \mathrm{L}$. The linear equation obtained is Absorbance $(y)=0.1719 \times(\mathrm{mg} / \mathrm{L})+0.191$. The specific correlation coefficient was $\left(R^{2}\right)=0.9999$. The obtained linear calibration equation was used through this study to determine the remaining dye concentration in the degraded dye solution after UV irradiation.

3.3.2. Photodegradation of Dye. First, $2 \mathrm{~g} / \mathrm{L}$ of the titanate nanotubes prepared at different temperatures was mixed with $100 \mathrm{~mL}$ of the synthetic MB solution. Next, the mixture was photoirradiated with UV light for $2 \mathrm{~h}$. The reaction mixture was stirred with a magnetic stirrer. The experiment was conducted at room temperature with an initial $\mathrm{MB}$ concentration of $9 \mathrm{mg} / \mathrm{L}$. The $\mathrm{pH}$ of the medium was $\sim 7$. Kinetically, within 20 min of photoirradiation, $\sim 99 \%$ of the dye had degraded. Hence, a $20 \mathrm{~min}$ photoirradiation time was identified as the equilibrium time for the dye photodegradation. No further acceleration of dye degradation was observed over an additional $100 \mathrm{~min}$ of irradiation time. The dye degradation efficiency was almost the same for each as-prepared titanate nanotube sample except that prepared at $180^{\circ} \mathrm{C}$ (Figure 11). The higher specific surface area $\left(186.8 \mathrm{~m}^{2} / \mathrm{g}\right)$ allows more of the organic pollutant to be adsorbed onto the photocatalyst surface, while the high pore volume results in a faster diffusion of various reaction products during the photocatalytic reaction. All these factors contributed to enhancing the photocatalytic activity [42]. However, unlike the conventional adsorption of other aquatic contaminants on the adsorbent, which depends on both the particle size and the surface area 


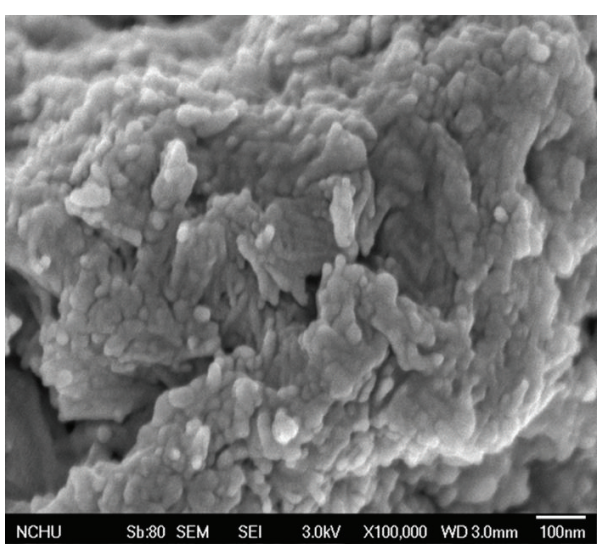

(a)

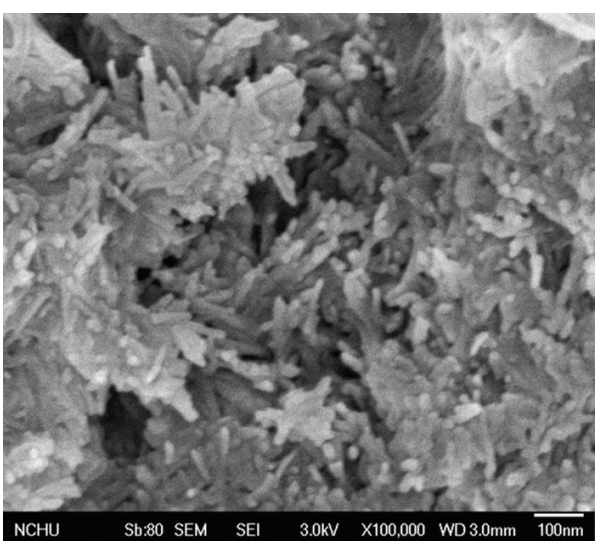

(c)

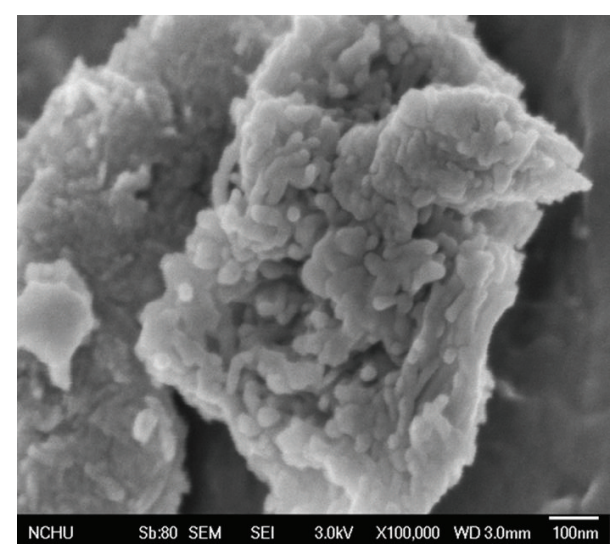

(b)

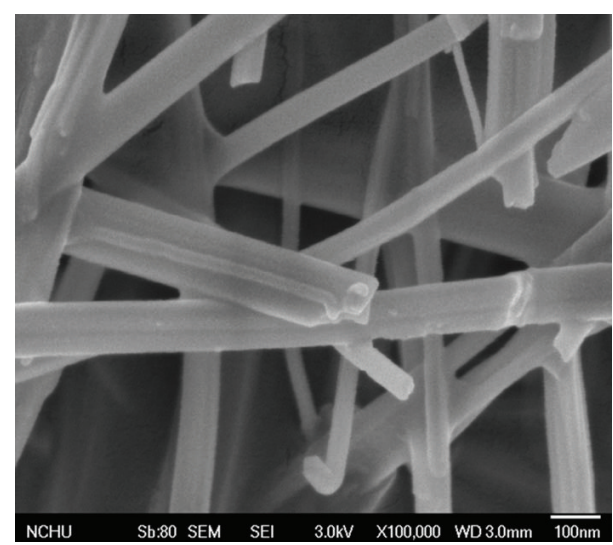

(d)

FIgURE 7: SEM images of the samples prepared at different reaction temperatures: (a) $110^{\circ} \mathrm{C}$, (b) $130^{\circ} \mathrm{C}$, (c) $150^{\circ} \mathrm{C}$, and (d) $180^{\circ} \mathrm{C}$.

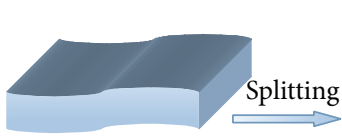

(a)

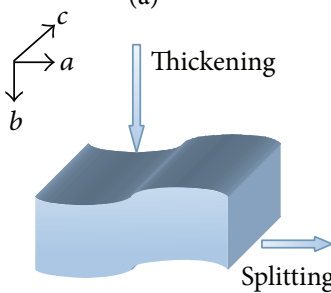

(d)

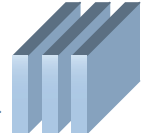

(b)

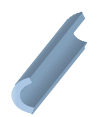

(c)

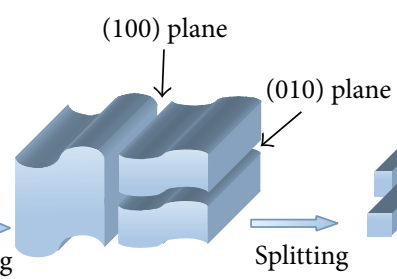

(e)

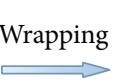

FIGURE 8: Nanotube/nanorod formation mechanism.

of the particle [43], the photodegradation of aquatic organic contaminants (here, dye) may also depend on the photon absorption and electronic transition between the organic dye (in the presence of oxygen) and titanate nanotubes, which in turn may enhance the MB degradation in the aquatic environment in the present study.
3.3.3. Photodegradation Mechanism. It is well known that anatase, titanate, and Degussa P-25 are not excited by visible light but can be used to degrade most colored contaminants because of their photosensitization effect [44]. Titanate nanotubes have a large BET surface area of approximately $186.8 \mathrm{~m}^{2} / \mathrm{g}$ and therefore show a high adsorption capacity, which is beneficial for collecting organic contaminate molecules such as $\mathrm{MB}$. Under UV irradiation, the $\mathrm{MB}$ molecules were adsorbed onto the nanotube surfaces, and the produced electrons were transferred to titanate nanotubes and then injected into the conduction band of the anatase nanoparticles connected with these nanotubes through the nanotube channels [45]. This injective process could also be directly performed by radical MB molecules [46]. The injected electrons were captured by the surface-adsorbed $\mathrm{O}_{2}$ molecules to yield $\mathrm{O}_{2}{ }^{--}$and $\mathrm{HO}^{\bullet}$ radical ions, among others. Finally, the MB molecules could be quickly mineralized by the radical ions. Due to the anatase nanoparticles' high absorption capacity and high concentration of excited electrons, the MB molecules adsorbed onto the surface of anatase will be easily photodegraded; thus, the photocatalytic activity of the nanocomposite is substantially improved. The 


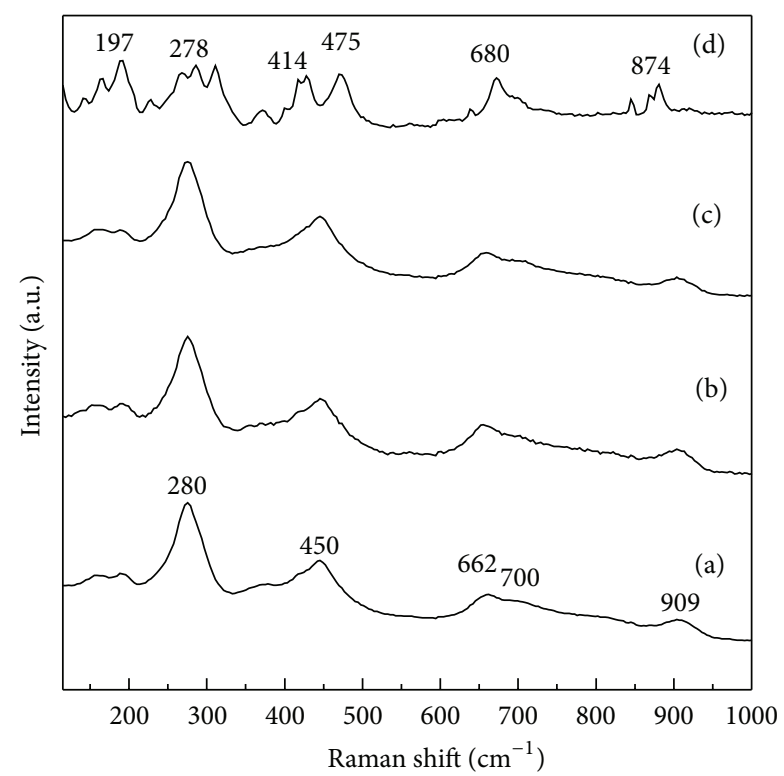

FIGURE 9: Raman spectra of the samples prepared at different reaction temperatures: (a) $110^{\circ} \mathrm{C}$, (b) $130^{\circ} \mathrm{C}$, (c) $150^{\circ} \mathrm{C}$, and (d) $180^{\circ} \mathrm{C}$.

probable photodegradation mechanism of dye under UV light using titanate nanotubes is shown as follows [47]:

$$
\begin{gathered}
\text { dye }+h v \longrightarrow \text { dye }^{*} \\
\text { dye }{ }^{*}+\mathrm{TiO}_{2} \longrightarrow \text { dye }+\mathrm{TiO}_{2}(\mathrm{e}) \\
\mathrm{TiO}_{2}(\mathrm{e})+\mathrm{O}_{2} \longrightarrow \mathrm{TiO}_{2}+\mathrm{O}_{2}{ }^{\cdot-} \\
\mathrm{O}_{2}{ }^{--}+\mathrm{TiO}_{2}(\mathrm{e})+2 \mathrm{H}^{+} \longrightarrow \mathrm{H}_{2} \mathrm{O}_{2} \\
\mathrm{H}_{2} \mathrm{O}_{2}+\mathrm{TiO}_{2}(\mathrm{e}) \longrightarrow \mathrm{OH}^{\bullet}+\mathrm{OH}^{-}
\end{gathered}
$$

dye $e^{\bullet} \mathrm{O}_{2}\left(\right.$ or $\mathrm{O}_{2}{ }^{--}$or $\left.{ }^{\bullet} \mathrm{OH}\right)$

$\longrightarrow$ peroxylated or hydroxylated intermediates

\section{$\longrightarrow$ degraded or mineralized products}

According to the above formulae, radicals and hydroxyl groups play a key role in the degradation process, and a greater amount of radicals or hydroxyl groups corresponds to better photocatalytic activity. In the present case, the catalyst, which obeyed a similar mechanism of dye photodegradation, contained hydroxyl groups, which means that the synthesized samples have good potential for photocatalytic applications. The maximum absorption boundaries of the samples mean that the samples can absorb more photons under UV light or sunlight [36].

\section{Conclusions}

A hydrothermal method was explored for the synthesis of titanate nanotubes. The nanotubes were characterized by SEM, TEM, and FTIR studies. The particles' scattering behavior was investigated by Raman studies. The surface area

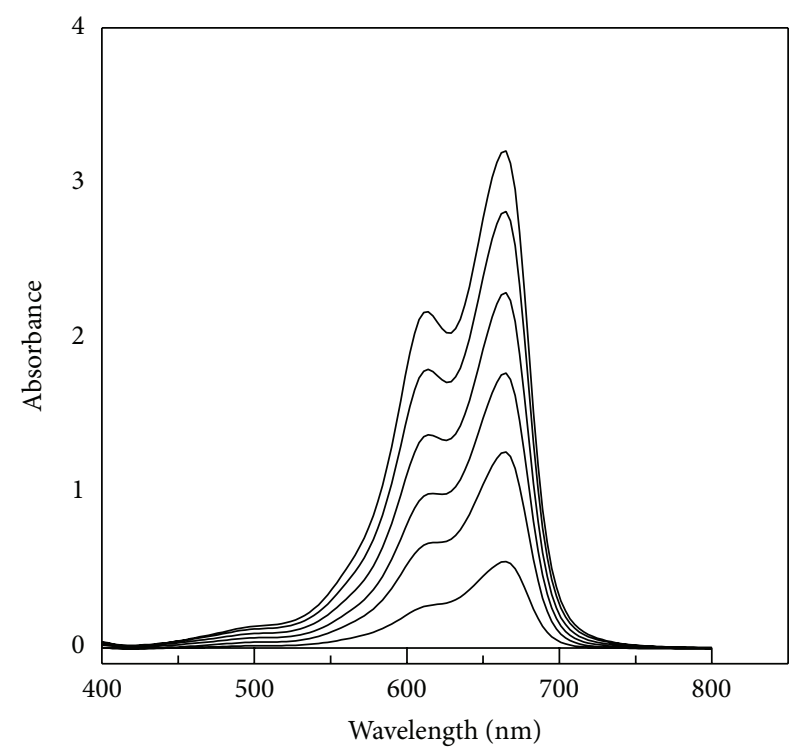

FIGURE 10: UV-Visible spectra of the dye at different concentrations at room temperature: $0,3,6,9,12,15$, and $18 \mathrm{mg} / \mathrm{L}$.

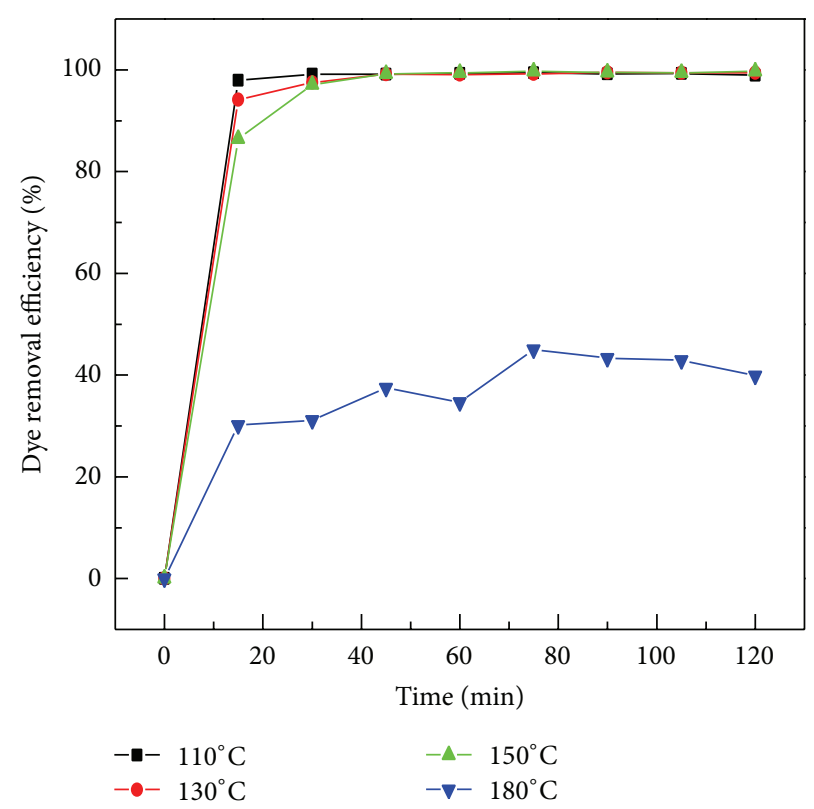

Figure 11: Dye degradation (\%) by the as-prepared nanotubes.

of the nanotubes was determined by BET analysis. It was observed that the surface area of the synthesized nanotubes is governed by the hydrothermal temperature and reaction time. At $130^{\circ} \mathrm{C}$ and $24 \mathrm{~h}$ of reaction time, the surface area of the titanate nanotubes was $186.8 \mathrm{~m}^{2} / \mathrm{g}$. The photocatalytic activity of the synthesized nanotubes for dye degradation was investigated using a dye-contaminated aqueous solution. The equilibrium time for dye degradation was $20 \mathrm{~min}$. At equilibrium, $99 \%$ of the MB was degraded from the aqueous media by UV irradiation when the initial dye concentration was $9 \mathrm{mg} / \mathrm{L}$. The maximum absorption boundaries of the dye-contaminated samples mean that the samples can absorb 
more photons under UV light or sunlight. Hence, the synthesized titanate nanotubes are a suitable photocatalyst for the degradation of $\mathrm{MB}$, an organic dye, from aqueous media.

\section{Conflict of Interests}

The authors declare that there is no conflict of interests regarding the publication of this paper.

\section{Acknowledgment}

The authors would like to express their gratitude to Ph.D. program of Harbin University of Commerce for supporting this research under Grant 14LG13.

\section{References}

[1] B. O'Regan and M. Grätzel, "A low-cost, high-efficiency solar cell based on dye-sensitized colloidal $\mathrm{TiO}_{2}$ films," Nature, vol. 353, pp. 737-740, 1991.

[2] A. Fujishima, T. N. Rao, and D. A. Tryk, "Titanium dioxide photocatalysis," Journal of Photochemistry and Photobiology C: Photochemistry Reviews, vol. 1, no. 1, pp. 1-21, 2000.

[3] S. A. Al-Thabaiti, R. Hahn, N. Liu et al., " $\mathrm{NH}_{3}$ treatment of $\mathrm{TiO}_{2}$ nanotubes: from $\mathrm{N}$-doping to semimetallic conductivity," Chemical Communications, vol. 50, no. 59, pp. 7960-7963, 2014.

[4] T. Rajh, Z. Saponjic, J. Liu et al., "Charge transfer across the nanocrystalline-DNA interface: probing DNA recognition," Nano Letters, vol. 4, no. 6, pp. 1017-1023, 2004.

[5] H. Tokuhisa and P. T. Hammond, "Solid-state photovoltaic thin films using $\mathrm{TiO}_{2}$, organic dyes, and layer-by-layer polyelectrolyte nanocomposites," Advanced Functional Materials, vol. 13, no. 11, pp. 831-839, 2003.

[6] A. Pal and S. K. Maji, "Arsine-induced formation of silver nanoparticles in micellar medium. Application to spectrophotometric determination of arsenic," Chemia Analityczna, vol. 50, no. 6, pp. 1077-1086, 2005.

[7] A. Pal and S. K. Maji, "Spectrophotometric determination of arsenic via nanogold formation in micellar medium," Indian Journal of Chemistry A: Inorganic, Physical, Theoretical and Analytical Chemistry, vol. 45, no. 5, pp. 1178-1182, 2006.

[8] I. Srnová-Šloufová, F. Lednický, A. Gemperle, and J. Gemperlová, "Core-shell (Ag)Au bimetallic nanoparticles: analysis of transmission electron microscopy images," Langmuir, vol. 16, no. 25, pp. 9928-9935, 2000.

[9] F. Bensebaa, N. Patrito, Y. le Page, P. L'Ecuyer, and D. Wang, "Tunable platinum-ruthenium nanoparticle properties using microwave synthesis," Journal of Materials Chemistry, vol. 14, no. 22, pp. 3378-3384, 2004.

[10] J. Yang, J. Yang Lee, and H.-P. Too, "Phase-transfer identification of core-shell structures in bimetallic nanoparticles," Plasmonics, vol. 1, no. 1, pp. 67-78, 2006.

[11] M. A. Fox and M. T. Dulay, "Heterogeneous photocatalysis," Chemical Reviews, vol. 93, no. 1, pp. 341-357, 1993.

[12] Q. Kang, J. Cao, Y. Zhang, L. Liu, H. Xu, and J. Ye, "Reduced $\mathrm{TiO}_{2}$ nanotube arrays for photoelectrochemical water splitting," Journal of Materials Chemistry A, vol. 1, no. 18, pp. 5766-5774, 2013.

[13] T. N. Obee and R. T. Brown, “ $\mathrm{TiO}_{2}$ photocatalysis for indoor air applications: effects of humidity and trace contaminant levels on the oxidation rates of Formaldehyde, Toluene, and 1,3Butadiene," Environmental Science and Technology, vol. 29, pp. 1223-1231, 1995.

[14] C. Ooka, H. Yoshida, K. Suzuki, and T. Hattori, "Highly hydrophobic $\mathrm{TiO}_{2}$ pillared clay for photocatalytic degradation of organic compounds in water," Microporous and Mesoporous Materials, vol. 67, no. 2-3, pp. 143-150, 2004.

[15] M. Qamar, M. Saquib, and M. Muneer, "Photocatalytic degradation of two selected dye derivatives, chromotrope $2 \mathrm{~B}$ and amido black 10B, in aqueous suspensions of titanium dioxide," Dyes and Pigments, vol. 65, no. 1, pp. 1-9, 2005.

[16] W. Wang, B. Gu, L. Liang, W. A. Hamilton, and D. J. Wesolowski, "Synthesis of rutile $\left(\alpha-\mathrm{TiO}_{2}\right)$ nanocrystals with controlled size and shape by low-temperature hydrolysis: effects of solvent composition," Journal of Physical Chemistry B, vol. 108, no. 39, pp. 14789-14792, 2004.

[17] M. Visca and E. J. Matijević, "Preparation of uniform colloidal dispersions by chemical reactions in aerosols. I. Spherical particles of titanium dioxide," Journal of Colloid and Interface Science, vol. 68, no. 2, pp. 308-319, 1979.

[18] H. K. Park, Y. T. Moon, D. K. Kim, and C. H. Kim, "Formation of monodisperse spherical $\mathrm{TiO}_{2}$ powders by thermal hydrolysis of $\mathrm{Ti}\left(\mathrm{SO}_{4}\right)_{2}$," Journal of the American Ceramic Society, vol. 79, no. 10, pp. 2727-2732, 1996.

[19] E. A. Barringer and H. K. Bowen, "High-purity, monodisperse $\mathrm{TiO}_{2}$ powders by hydrolysis of titanium tetraethoxide. 1. Synthesis and physical properties," Langmuir, vol. 1, no. 4, pp. 414420, 1985.

[20] Q.-H. Zhang, L. Gao, and J.-K. Guo, "Preparation and characterization of nanosized $\mathrm{TiO}_{2}$ powders from aqueous $\mathrm{TiCl}_{4}$ solution," Nanostructured Materials, vol. 11, pp. 1293-1300, 1999.

[21] F. Cavani, E. Foresti, F. Parrinello, and F. Trifirò, "Role of the chemistry of solutions of titanium ions in determining the structure of V/Ti/O catalysts," Applied Catalysis, vol. 38, no. 2, pp. 311-325, 1988.

[22] T. Kasuga, M. Hiramatsu, A. Hoson, T. Sekino, and K. Niihara, "Formation of titanium oxide nanotube," Langmuir, vol. 14, no. 12, pp. 3160-3163, 1998.

[23] T. Kasuga, M. Hiramatsu, A. Hoson, T. Sekino, and K. Niihara, "Titania nanotubes prepared by chemical processing," Advanced Materials, vol. 11, no. 15, pp. 1307-1311, 1999.

[24] Y. Q. Wang, G. Q. Hu, X. F. Duan, H. L. Sun, and Q. K. Xue, "Microstructure and formation mechanism of titanium dioxide nanotubes," Chemical Physics Letters, vol. 365, no. 5-6, pp. 427431, 2002.

[25] X. Sun and Y. Li, "Synthesis and characterization of ionexchangeable titanate nanotubes," Chemistry-A European Journal, vol. 9, no. 10, pp. 2229-2238, 2003.

[26] N. D. Lourenço, J. M. Novais, and H. M. Pinheiro, "Effect of some operational parameters on textile dye biodegradation in a sequential batch reactor," Journal of Biotechnology, vol. 89, no. 2-3, pp. 163-174, 2001.

[27] Z. Sun, Y. Chen, Q. Ke, Y. Yang, and J. Yuan, "Photocatalytic degradation of a cationic azo dye by $\mathrm{TiO}_{2}$ /bentonite nanocomposite," Journal of Photochemistry and Photobiology A: Chemistry, vol. 149, pp. 169-174, 2002.

[28] C.-C. Wang, L.-C. Juang, T.-C. Hsu, C.-K. Lee, J.-F. Lee, and F.-C. Huang, "Adsorption of basic dyes onto montmorillonite," Journal of Colloid and Interface Science, vol. 273, no. 1, pp. 80-86, 2004. 
[29] A. Andrzejewska, A. Krysztafkiewicz, and T. Jesionowski, "Treatment of textile dye wastewater using modified silica," Dyes and Pigments, vol. 75, no. 1, pp. 116-124, 2007.

[30] A. Andrzejewska, A. Krysztafkiewicz, and T. Jesionowski, "Adsorption of organic dyes on the aminosilane modified $\mathrm{TiO}_{2}$ surface," Dyes and Pigments, vol. 62, no. 2, pp. 121-130, 2004.

[31] G. Crini, "Non-conventional low-cost adsorbents for dye removal: a review," Bioresource Technology, vol. 97, no. 9, pp. 1061-1085, 2006.

[32] J. Yu, H. Yu, B. Cheng, X. Zhao, and Q. Zhang, "Preparation and photocatalytic activity of mesoporous anatase $\mathrm{TiO}_{2}$ nanofibers by a hydrothermal method," Journal of Photochemistry and Photobiology A: Chemistry, vol. 18, no. 2, pp. 121-127, 2006.

[33] Y. Xiao, L. Dang, L. An, S. Bai, and Z. Lei, "Photocatalytic degradation of rhodamine $\mathrm{B}$ and phenol by $\mathrm{TiO}_{2}$ loaded on mesoporous graphitic carbon," Chinese Journal of Catalysis, vol. 29, no. 1, pp. 31-36, 2008.

[34] H. Choia, E. Stathatosb, and D. D. Dionysioua, "Photocatalytic $\mathrm{TiO}_{2}$ films and membranes for the development of efficient wastewater treatment and reuse systems," Desalination, vol. 202, no. 1-3, pp. 199-206, 2007.

[35] M. Wei, Y. Konishi, H. Zhou, H. Sugihara, and H. Arakawa, "Formation of nanotubes $\mathrm{TiO}_{2}$ from layered titanate particles by a soft chemical process," Solid State Communications, vol.133, no. 8, pp. 493-497, 2005.

[36] G.-S. Guo, C.-N. He, Z.-H. Wang, F.-B. Gu, and D.-M. Han, "Synthesis of titania and titanate nanomaterials and their application in environmental analytical chemistry," Talanta, vol. 72, no. 5, pp. 1687-1692, 2007.

[37] L.-H. Huang, C. Sun, and Y.-L. Liu, "Pt/N-codoped $\mathrm{TiO}_{2}$ nanotubes and its photocatalytic activity under visible light," Applied Surface Science, vol. 253, no. 17, pp. 7029-7035, 2007.

[38] V. P. Godbole, Y.-S. Kim, M. A. Dar, G.-S. Kim, and H.-S. Shin, "Synthesis of titanate nanotubes and its processing by different methods," Electrochimica Acta, vol. 52, no. 4, pp. 1781-1787, 2006.

[39] K. R. Zhu, Y. Yuan, M. S. Zhang, J. M. Hong, Y. Deng, and Z. Yin, "Structural transformation from $\mathrm{NaHTi}_{3} \mathrm{O}_{7}$ nanotube to $\mathrm{Na}_{2} \mathrm{Ti}_{6} \mathrm{O}_{13}$ nanorod," Solid State Communications, vol. 144, no. 10-11, pp. 450-453, 2007.

[40] H. Tokudome and M. Miyauchi, "N-doped $\mathrm{TiO}_{2}$ nanotube with visible light activity," Chemistry Letters, vol. 33, no. 9, pp. 11081109, 2004.

[41] D. Wu, J. Liu, X. Zhao, A. Li, Y. Chen, and N. Ming, "Sequence of events for the formation of titanate nanotubes, nanofibers, nanowires, and nanobelts," Chemistry of Materials, vol. 18, no. 2, pp. 547-553, 2006.

[42] J. Yu, H. Yu, B. Cheng, and C. Trapalis, "Effects of calcination temperature on the microstructures and photocatalytic activity of titanate nanotubes," Journal of Molecular Catalysis A: Chemical, vol. 249, no. 1-2, pp. 135-142, 2006.

[43] S. K. Maji, A. Pal, and T. Pal, "Arsenic removal from aqueous solutions by adsorption on laterite soil," Journal of Environmental Science and Health, Part A: Toxic/Hazardous Substances and Environmenta, vol. 42, no. 4, pp. 453-462, 2007.

[44] D. Chatterjee and S. Dasgupta, "Visible light induced photocatalytic degradation of organic pollutants," Journal of Photochemistry and Photobiology C: Photochemistry Reviews, vol. 6, pp. 186-205, 2005.

[45] T. Tachikawa, S. Tojo, M. Fujitsuka, T. Sekino, and T. Majima, "Photoinduced charge separation in titania nanotubes," The Journal of Physical Chemistry B, vol. 110, no. 29, pp. 14055-14059, 2006.
[46] K. Vinodgopal, D. E. Wynkoop, and P. V. Kamat, "Environmental photochemistry on semiconductor surfaces: photosensitized degradation of a textile azo dye, Acid Orange 7, on $\mathrm{TiO}_{2}$ particles using visible light," Environmental Science and Technology, vol. 30, no. 5, pp. 1660-1666, 1996.

[47] J. Li, W. Ma, C. Chen, J. Zhao, H. Zhu, and X. Gao, "Photodegradation of dye pollutants on one-dimensional $\mathrm{TiO}_{2}$ nanoparticles under UV and visible irradiation," Journal of Molecular Catalysis A: Chemical, vol. 261, no. 1, pp. 131-138, 2007. 

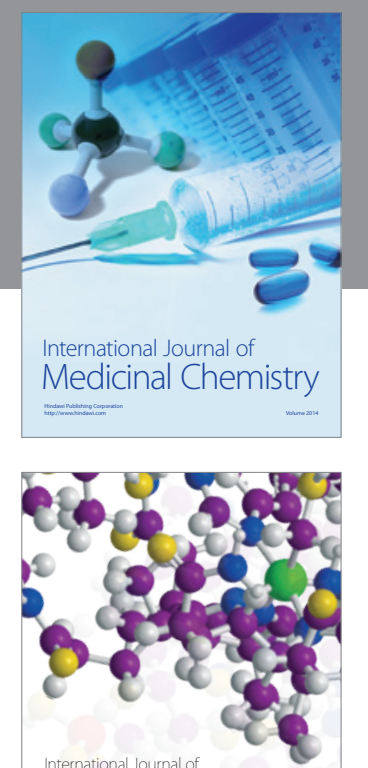

\section{Carbohydrate} Chemistry

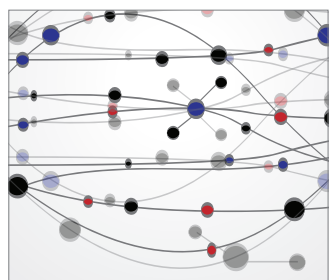

The Scientific World Journal
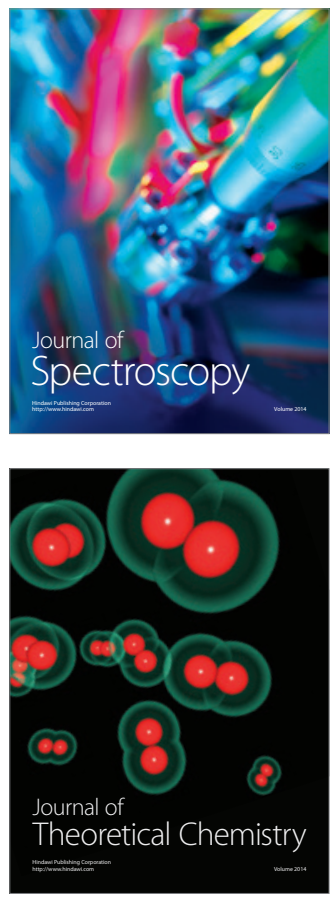
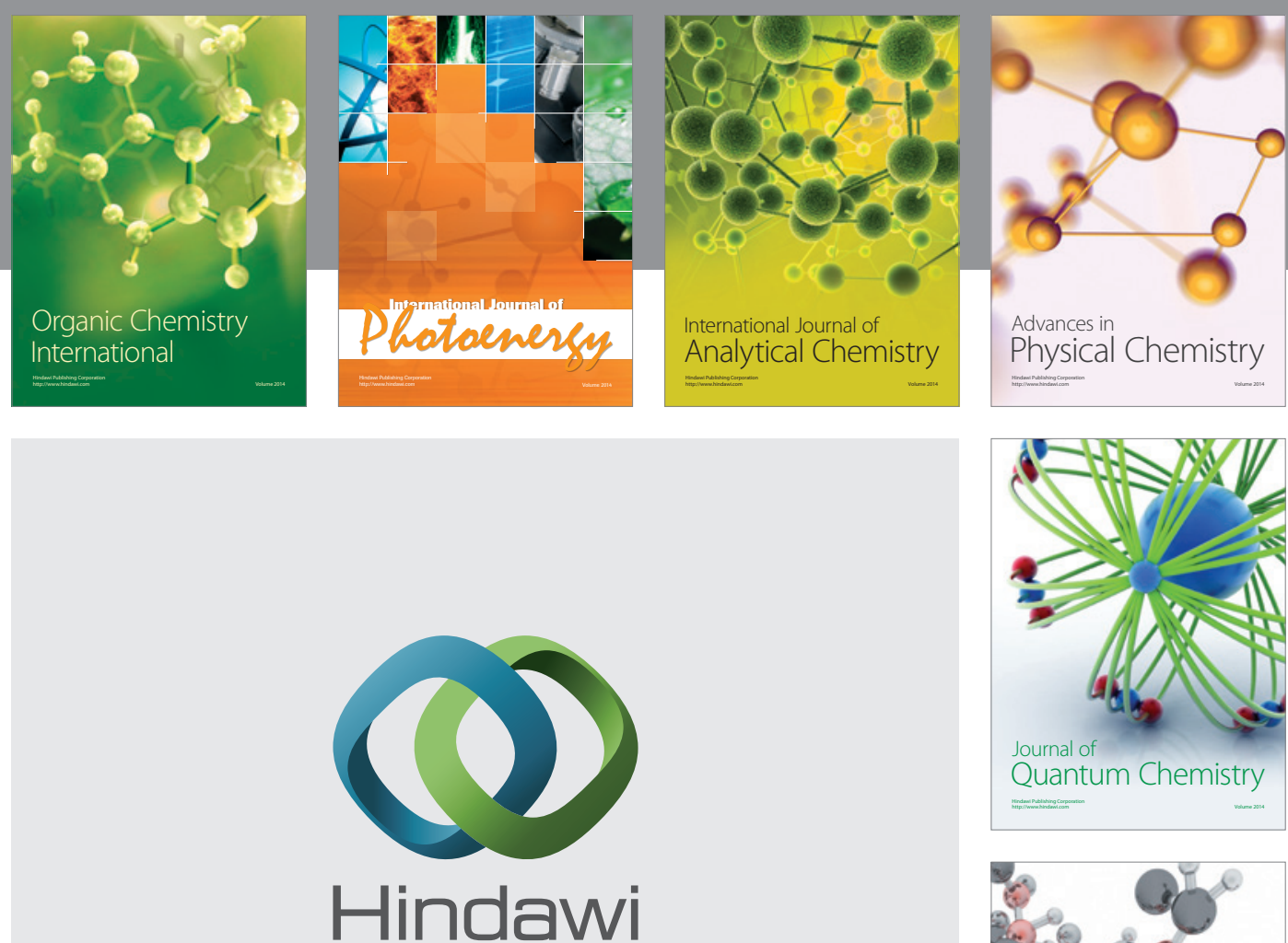

Submit your manuscripts at

http://www.hindawi.com

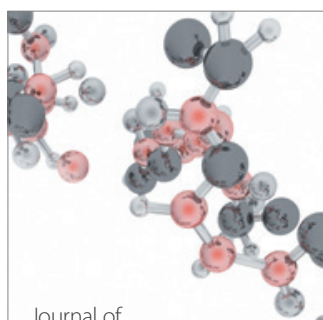

Analytical Methods

in Chemistry

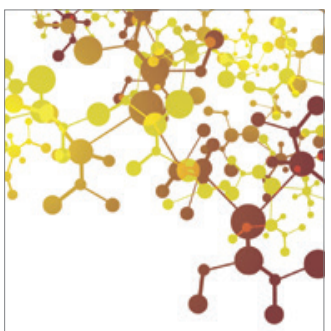

Journal of

Applied Chemistry

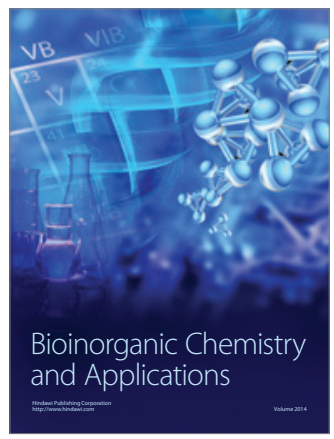

Inorganic Chemistry
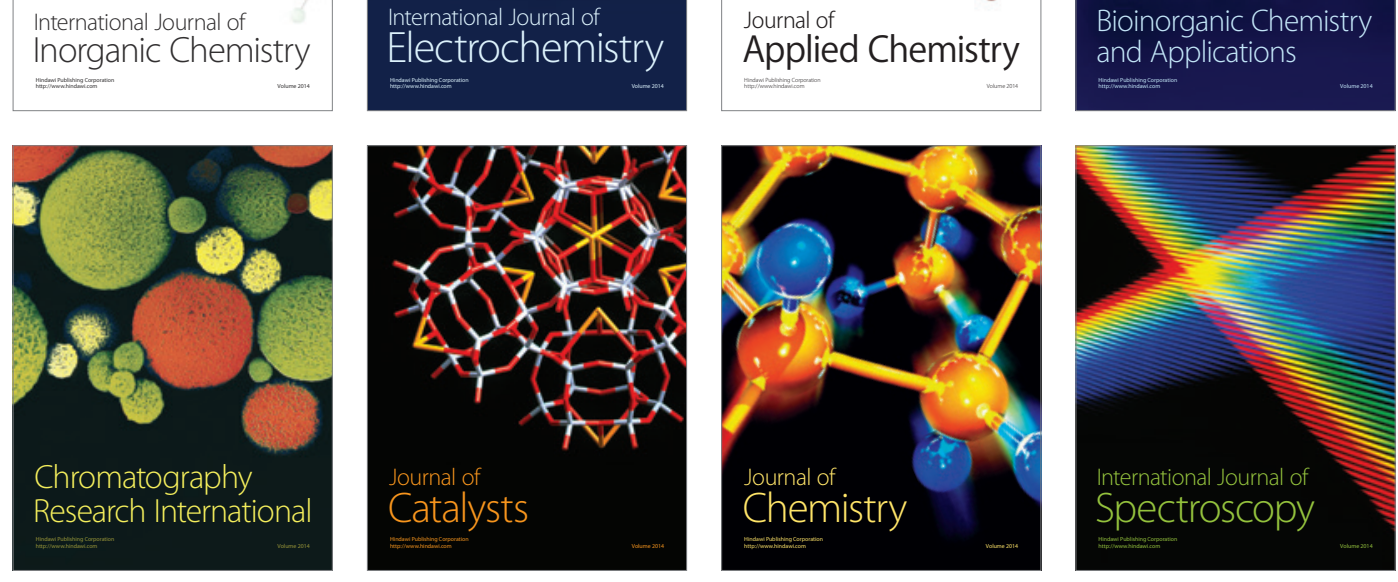